\title{
Grand Challenge for the Future of Freshwater Ecosystems
}

\author{
Stuart E. Bunn * \\ Australian Rivers Institute, Griffith University, Brisbane, QLD, Australia
}

Keywords: water crisis, pollution, dams, river health, freshwater biodiversity, sustainable development goals, environmental flows

\section{INTRODUCTION}

We live on a blue planet and, although much of the water is in the oceans, it can be argued that there is abundant freshwater to sustain human society: some $93,000 \mathrm{~km}^{3}$ is in lakes and rivers alone and much more is stored in groundwater or as ice ${ }^{1}$. However, freshwater is not distributed uniformly in space or time across the globe, nor often in relation to patterns of human settlement. To compound this problem, intensive human activities have further diminished available water supplies through overuse and pollution from point and non-point sources. As a consequence, $80 \%$ of the world's population is exposed to high levels of threat to water security (Vörösmarty et al., 2010).

In the developed world, massive investments in water infrastructure have been made to offset the threat to human water security (Vörösmarty et al., 2010). However, these technical and primarily "end-of-pipe" solutions have come at considerable cost to the natural environment and there has been no similar level of investment to protect aquatic ecosystems. As a result, the threat to freshwater biodiversity remains high in much of the developed and developing world. Declining water quality and quantity, habitat modification, overfishing, and biological invasions pose major threats across the globe (Dudgeon et al., 2006).

These human pressures continue to grow with no sign of abating (Vörösmarty et al., 2013) and are likely to dominate the threats to most freshwater ecosystems over the next three decades (Settele et al., 2014). Climate change will compound these problems and is already affecting freshwater ecosystems in regions that until now have been relatively unimpaired by human activity. Rising water temperatures are driving shifts in freshwater species distributions and will worsen water quality problems, especially in systems with high loading of nutrients (Settele et al., 2014). Changes in precipitation will substantially alter ecologically important attributes of flow regimes in many rivers and wetlands (Döll and Bunn, 2014). Many of these environmental changes impact on important goods and services provided by freshwater ecosystems (e.g., clean water, fisheries) and will further compound the challenges for human water security.

There is little dispute that we have entered the Anthropocene for freshwater ecosystems. Reference to "water shortages" began to rise in English publications at the start of the last century but declined in prevalence in the 1970's, associated with an increase in the use of the term "water crisis" (Figure 1). Throughout this period, the term "water demand" has continued to increase in prevalence and "global water crisis" has emerged as a new moniker for the twenty-first century. Our past approach to water management is unlikely to meet growing human water needs in the face of accelerated change to our freshwater ecosystems, let alone address the consequences of continuing environmental decline.

The aim of this "grand challenge" article is to highlight what can be done to address these problems, from global scale governance initiatives to local-scale on-ground actions, aimed at tackling problems at their source. I also wish to explore what more we can do to

\footnotetext{
${ }_{1}$ http://water.usgs.gov/edu/earthhowmuch.html
} 


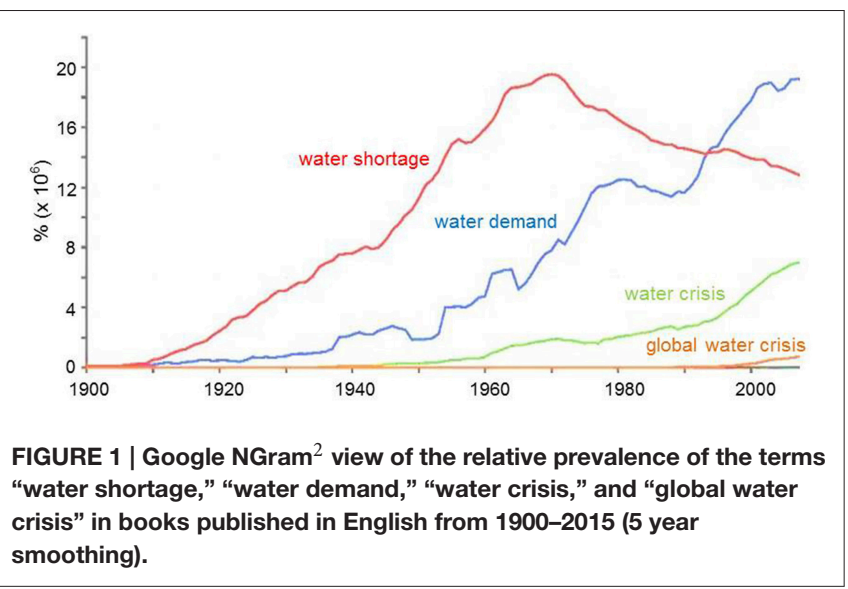

improve engagement among the scientific and technical disciplines with interests in freshwater management, and more effectively communicate the cause and consequence of these problems, and possible solutions to them, to decision makers and the broader community.

\section{GLOBAL INITIATIVES}

Although water management has been traditionally viewed as a local- or regional-scale problem, there are compelling arguments to also take a global perspective. Water scarcity can be driven not only by the variable and changing climate but also by the movement of water through global trade (Vörösmarty et al., 2015). Such trade can exacerbate the problem by externalizing water pollution from agriculture or industry to countries with lax environmental regulation. International agreements on water stewardship will be required to ensure social equity and sustainability of our freshwater systems (Vörösmarty et al., 2015). Understanding and quantifying these externalities is a role for science.

The setting of Millennium Development Goals provided an initial global commitment to environmental sustainability (Goal 7) but the only target for freshwater (7C) was focused on safe drinking water and sanitation, while the target to reduce biodiversity loss (7B) dealt primarily with terrestrial and marine ecosystems. The omission of freshwater ecosystems from the latter was a significant oversight, given that rivers and lakes sustain nearly $10 \%$ of all described animal species, including $40 \%$ of the world's fish diversity and a third of all vertebrate species (Balian et al., 2008).

Early working drafts for the Post-2015 Development Agenda took a similar perspective on freshwater ${ }^{3}$, prompting the following statement from the Budapest Water Summit in October 2013:4 "Safeguarding and rehabilitating ecosystems in 21st Century water resources development approaches will be an important shift toward sustainability. Unintended impacts to

\footnotetext{
${ }^{2}$ https://books.google.com/ngrams

${ }^{3}$ https://sustainabledevelopment.un.org/

${ }^{4} \mathrm{http}: / / \mathrm{www}$.budapestwatersummit.hu/budapest-water-summit/budapeststatement/
}

ecosystems in the name of water uses are contrary to the aspirations of a sustainable water future."

It is pleasing to note that the agreed Sustainable Development Goals (SDGs) include targets to improve water quality by 2030 by reducing pollution (6.3) and to protect and restore water-related ecosystems by $2020(6.6)^{5}$. The ecosystems goal (15) also now includes specific mention of freshwater ecosystems and wetlands (Target 15.1).

The effectiveness of these targets, however, will ultimately depend on the robustness of the agreed indicators to assess progress, and the commitment of governments to achieve them. The proposed indicator for Target 6.6, wetland extent, is unlikely to provide an adequate measure of the state of freshwater ecosystems. Development of more appropriate indicators and transparent reporting of progress will be required. Several other SDGs, including those addressing hunger (Goal 2), health (Goal 3), and affordable clean energy (Goal 7), are intimately linked to water and a key challenge will be to understand these interdependencies and avoid perverse outcomes for freshwater ecosystems.

Other international agreements, such as the UN Watercourses Convention and the UNECE Water Convention, could play a significant role in strengthening international laws for freshwater conservation and, in particular, address transboundary water challenges (Rieu-Clarke and Kinna, 2014). Improved collaboration and coordination among these and other intergovernmental initiatives, (e.g., the 5th Joint Work Plan between the Convention on Biological Diversity and the Ramsar Convention on Wetlands ${ }^{6}$ ) will undoubtedly be important to achieve the water SDGs and improve biodiversity conservation for freshwaters.

\section{LOCAL AND REGIONAL SCALE ACTIONS}

There is much that can be done to reduce the threat to freshwater ecosystems at the local and regional scales, both in terms of quantity and quality, but it is clear that management is often more a social, political and financial challenge rather than a purely technical one. Improving water-use efficiency in agriculturegrowing more food with less water-is a critical strategy for environmental and economic reasons. Australia halved water use per ha irrigated in the decade to 2003 (OECD, 2008), prior to the "Millennium" drought, and further reduced irrigation use from 2003 to 2011, while increasing gross value of production at the same time (National Sustainability Council, 2013). Most Australian cities also significantly reduced per capita water use during this period, through a range of demand management initiatives, and have maintained per capita consumption at about half that recorded prior to the drought.

Growing energy demand and a Rio+20 commitment to the use of Kyoto-compliant energy resources has triggered a new era of dam construction, with over 3700 hydroelectric dams currently planned or under construction (Zarfl et al., 2015).

\footnotetext{
${ }_{5}^{5}$ https://sustainabledevelopment.un.org/sdgs

${ }^{6}$ http://www.ramsar.org/sites/default/files/documents/pdf/moc/CBD-

Ramsar5thJWP_2011-2020.pdf
} 
This has the potential to significantly fragment many of the planet's remaining free-flowing large rivers. Freshwater scientists have an essential role to play in guiding the location, design, and operation of future dams, to ensure aquatic ecosystems are protected. Improved systematic planning tools are needed (see Hermoso et al., 2015a) that can assist water managers and decision makers to explore outcomes that are not only costeffective but also socially and environmentally acceptable. There is also a need to continue to improve our understanding of important flow-ecology relationships (Bunn and Arthington, 2002), and the development of practical tools for determining environmental flow requirements (Poff et al., 2010; Pahl-Wostl et al., 2013).

Reducing pollution is a key target under the water SDG. With respect to point source pollution from urban and industrial waste, this is more an economic and political issue, rather than a technical one. Developed countries have invested billions of dollars in wastewater treatment to reduce the threat to human water security and to meet environmental regulations, and developing countries will need to follow suit to achieve this goal. For example, China recently has committed two trillion RMB to tackle water pollution under its ambitious "Water Ten Plan $^{7} . "$

Tackling non-point (diffuse) pollution remains a greater challenge in both the developed and developing world. This is often a consequence of degraded or poorly managed riparian lands (Allan, 2004). Riparian management guidelines are available for many biomes, providing detailed technical advice for the protection and rehabilitation of streams and rivers. However, most restoration efforts have been ineffective to date: they are often poorly targeted or undertaken at the wrong spatial scale and, more importantly, do not consider social or economic aspects of the problem (Hermoso et al., 2012).

More research is required to fully understand the spatial pattern and scale of riparian influence on stream health (e.g., Sheldon et al., 2012) and a more systematic approach to rehabilitation planning is needed (e.g., Hermoso et al., 2015b). However, large-scale implementation of river and catchment rehabilitation is unlikely if there are impediments to funding or if governance arrangements preclude a coordinated and targeted approach.

${ }^{7} \mathrm{http} / / /$ chinawaterrisk.org/notices/new-water-ten-plan-to-safeguard-chinaswaters/

\section{FUTURE DIRECTIONS}

It is clear that freshwater science, governance and management have entered an era where we need to analyze and act across local and global scales (Vörösmarty et al., 2015). There is much we can do to meet human demands for water, food and energy, yet also protect biodiversity and other important assets of freshwater ecosystems at the same time. This will require adequate recognition of the environment as a user of water and overcoming the barrier effects of dams and levees to maintain or restore connectivity. It will also require a significant shift in investment to tackle pollution at its source, eliminating point source inputs and reducing diffuse pollution though more targeted riparian protection. A more integrated and systematic approach is needed, that embraces the social and economic dimensions of these problems and not just the biophysical. This is likely to require changes in governance, drawing on experiences in waterstressed systems from around the world (e.g., Grafton et al., 2012).

These local, regional, and global scale initiatives will require more effective engagement and collaboration between those traditionally involved in the water resource industry (engineers and hydrologists) and ecologists and social scientists. The professional societies supporting these groups hold separate meetings and publish their own specialist journals, with little interaction. We need to overcome these "cultural" barriers to develop a shared understanding of the challenges facing our freshwater systems and to seek more sustainable solutions.

There is also a compelling need to more effectively communicate the cause and consequence of these freshwater problems, and their possible solutions to the broader community. We over-estimate the level of "water literacy" of the general public (and politicians) and there is a need to raise awareness and dispel popular myths. We also need to get much better at quantifying the full costs and benefits of management actionsand the grave consequences of inaction.

\section{AUTHOR CONTRIBUTIONS}

The author confirms being the sole contributor of this work and approved it for publication.

\section{REFERENCES}

Allan, J. D. (2004). Landscape and riverscapes: the influence of land use on river ecosystems. Annu. Rev. Ecol. Evol. Syst. 35, 257-284. doi: 10.1146/annurev.ecolsys.35.120202.110122

Balian, E. V., Segers, H., Leveque, C., and Martens, K. (2008). The freshwater animal diversity assessment: an overview of the results. Hydrobiology 595, 627-637. doi: 10.1007/s10750-007-9246-3

Bunn, S. E., and Arthington, A. H. (2002). Basic principles and ecological consequences of altered flow regimes for aquatic biodiversity. Environ. Manage. 30, 492-507. doi: 10.1007/s00267-002-2737-0

Döll, P., and Bunn, S. E. (2014). "Cross-chapter box on the impact of climate change on freshwater ecosystems due to altered river flow regimes," in Climate Change 2014: Impacts, Adaptation, and Vulnerability. Part A: Global and Sectoral Aspects. Contribution of Working Group II to the Fifth Assessment Report of the Intergovernmental Panel on Climate Change, eds C. B. Field, V. R. Barros, D. J. Dokken, K. J. Mach, M. D. Mastrandrea, T. E. Bilir, M. Chatterjee, K. L. Ebi, Y. O. Estrada, R. C. Genova, B. Girma, E. S. Kissel, A. N. Levy, S. MacCracken, P. R. Mastrandrea and L. L. White (Cambridge, UK; New York, NY: Cambridge University Press), 143-146.

Dudgeon, D., Arthington, A. H., Gessner, M. O., Kawabata, Z. I., Knowler, D. J., Leveque, C., et al. (2006). Freshwater biodiversity: importance, 
threats, status and conservation challenges. Biol. Rev. 81, 163-182. doi: 10.1017/S1464793105006950

Grafton, R. Q., Pittock, J., Davis, R., Williams, J., Fu, G., Warburton, M., et al. (2012). Global insights into water resources, climate change and governance. Nat. Clim. Chang. 3, 315-321. doi: 10.1038/nclimate1746

Hermoso, V., Januchowski-Hartley, S. R., and Linke, S. (2015a). Systematic planning of disconnection to enhance conservation success in a modified world. Sci. Total Environ. 536, 1038-1044. doi: 10.1016/j.scitotenv.2015.07.120

Hermoso, V., Pantus, F., Olley, J., Linke, S., Mugodo, J., and Lea, P. (2012). Systematic planning for river rehabilitation: integrating multiple ecological and economic objectives in complex decision-making scenarios. Freshw. Biol. 58, 1-12. doi: 10.1111/j.1365-2427.2011.02693.x

Hermoso, V., Pantus, F., Olley, J., Linke, S., Mugodo, J., and Lea, P. (2015b). Prioritising catchment rehabilitation for multi objective management: an application from SE-Queensland, Australia. Ecol. Model. 316, 168-175. doi: 10.1016/j.ecolmodel.2015.08.017

National Sustainability Council (2013). Sustainable Australia Report 2013, Conversations with the Future. Canberra, ACT: DSEWPaC.

OECD (2008). Environmental Performance of Agriculture in OECD Countries Since 1990. Paris.

Pahl-Wostl, C., Arthington, A., Bogardi, J., Bunn, S. E., Hoff, H., Lebel, L., et al. (2013). Environmental flows and water governance: managing sustainable water uses. Curr. Opin. Environ. Sustain. 5, 341-351. doi: 10.1016/j.cosust.2013.06.009

Poff, N. L., Richter, B., Arthington, A. H., Bunn, S. E., Naiman, R. J., Apse, C., et al. (2010). The ecological limits of hydrologic alteration: a framework for developing regional environmental flow standards. Freshw. Biol. 55, 147-170. doi: 10.1111/j.1365-2427.2009.02204.x

Rieu-Clarke, A., and Kinna, R. (2014). Can two global UN water conventions effectively co-exist? Making the case for a 'package approach' to support institutional coordination. RECIEL 23, 15-31. doi: 10.1111/reel.12070

Settele, J., Scholes, R., Betts, R., Bunn, S., Leadley, P., Nepstad, D., et al. (2014). "Terrestrial and inland water systems," in Climate Change 2014: Impacts, Adaptation, and Vulnerability. Part A: Global and Sectoral Aspects. Contribution of Working Group II to the Fifth Assessment Report of the Intergovernmental Panel on Climate Change, eds C. B. Field, V. R. Barros, D. J. Dokken, K. J. Mach, M. D. Mastrandrea, T. E. Bilir, M. Chatterjee, K. L. Ebi, Y. O. Estrada, R. C. Genova, B. Girma, E. S. Kissel, A. N. Levy, S. MacCracken, P. R. Mastrandrea, and L. L. White (Cambridge, UK; New York, NY: Cambridge University Press), 271-359.

Sheldon, F., Peterson, E. E., Boone, E. L., Sippel, S., Bunn, S. E., and Harch, B. D. (2012). Identifying the spatial scale of land-use that most strongly influences overall river ecosystem health score. Ecol. Appl. 22, 2188-2203. doi: 10.1890/11-1792.1

Vörösmarty, C. J., McIntyre, P. B., Gessner, M. O., Dudgeon, D., Prusevich, A., Green, P. A., et al. (2010). Global threats to human water security and river biodiversity. Nature 467, 555-561. doi: 10.1038/nature 09440

Vörösmarty, C. J., Hoekstra, A. Y., Bunn, S. E., Conway, D., and Gupta, J. (2015). Fresh water goes global. Science 349, 478-479. doi: 10.1126/science. aac6009

Vörösmarty, C. J., Pahl-Wostl, C., Bunn, S. E., and Lawford, R. (2013). Global Water, the anthropocene and the transformation of a science. Curr. Opin. Environ. Sustain. 5, 539-550. doi: 10.1016/j.cosust.2013.10.005

Zarfl, C., Lumsdon, A. E., Berlekamp, J., Tydecks, L., and Tockner, K. (2015). A global boom in hydropower dam construction. Aquat. Sci. 77, 161-170. doi: $10.1007 /$ s00027-014-0377-0

Conflict of Interest Statement: The author declares that the research was conducted in the absence of any commercial or financial relationships that could be construed as a potential conflict of interest.

Copyright (c) 2016 Bunn. This is an open-access article distributed under the terms of the Creative Commons Attribution License (CC BY). The use, distribution or reproduction in other forums is permitted, provided the original author $(s)$ or licensor are credited and that the original publication in this journal is cited, in accordance with accepted academic practice. No use, distribution or reproduction is permitted which does not comply with these terms. 